\title{
The Effect of Flywheel Unbalance on Gear Noise in the Hydraulic Power Plant Turbo-Generator
}

Elias Tomeh

Technical University of Liberec, Department of Vehicles and Engines, Studentská 2, 46117 Liberec, Czech Republic

\begin{abstract}
The Effect of Flywheel Unbalance on Gear Noise in the Hydraulic Power Plant Turbo-Generator. Hydraulic power plants are systems that produce electrical energy with high investment costs. In order to fulfil their goals, investments should create conditions for a safe production of energy in a long lasting and reliable way, and with the required power and quality. These goals are possible to reach by an optional control process linked to a systematic monitoring of the operating machinery state, using the method of vibration diagnostics. Lately, there has been an increase of noise level in the hydraulic power plants.
\end{abstract}

\section{Introduction}

Technical diagnostics of machines and equipment based on vibration measurement is currently applied in all industry sectors with substantial economic effect.

Achieved results in operating application of diagnostics (reducing maintenance costs and increasing reliability of machines) confirm that the diagnostics is a necessity for the operation of modern machines and equipment. Vibration measurements, in addition to early identification of malicious damage to the components and groups of monitored systems, also objectively evaluate the quality of manufacturing, assembly and adjustment of new or repaired machines. Thanks to the periodic evaluation of measurements, inexpensive measures enabling to prevent damage can usually be designed and implemented as well.

In the technically advanced countries, a maintenance based on the actual determination of the reported system condition, is applied in hydroelectric power plants. This means that:

- $\quad$ Shutdown of machines will only be made in cases where it is required because of their technical condition,

- Machine components are changed only in the event of wear or damage,

- $\quad$ Rotor balancing is performed only when it exceeds the prescribed limits,

- $\quad$ Alignment adjustment of the machine is performed when the deviation is large.

Abroad, in hydroelectric power plants, the vibration measurement is used for operational condition monitoring (in addition to the measurement of other variables such as bearing temperatures). The relative vibration of shaft is measured with proximity displacement sensor and the absolute vibration at the bearing point is identified.

In accordance with international knowledge, measurements of the velocity of absolute vibration were taken on TG machine. After general maintenance in the body of the small hydroelectric power plant, an increased vibration occurred at the designated measuring points. See Figure 1.

Acceleration sensors at the mentioned points were fixed by a permanent magnet. During the measurement, the machine was operating in a steady mode with a constant generator power of $100 \mathrm{~kW}$.

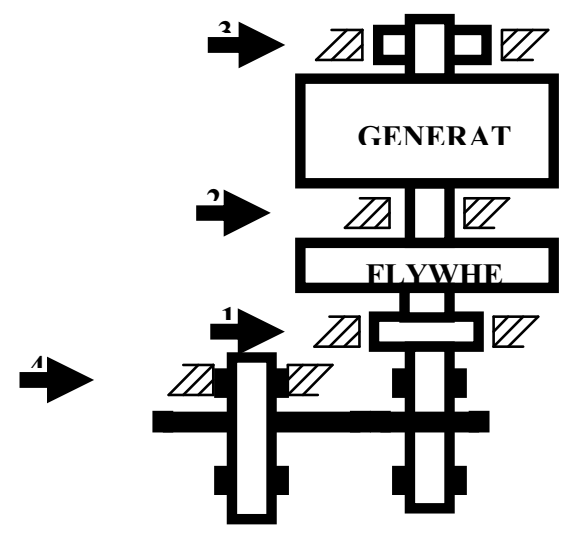

Figure 1. Points of measurement of vibration spectrum of the Turbo Generator TG

Corresponding author: elias.tomeh@tul.cz 
The overall level of machine vibration are assessed according to the effective value of the vibration velocity

$$
v_{e f}=\sqrt{\left(\frac{1}{T} \cdot \int_{0}^{T} v^{2}(t) d t\right),}
$$

Where:

$\mathbf{v}(\mathbf{t}) \ldots$ is time-dependent vibration velocity $\left[\mathrm{mm} \cdot \mathrm{s}^{-1}\right]$,

$\mathbf{v}_{\text {ef }} \ldots$ corresponding total velocity value $\left[\mathrm{mm} \cdot \mathrm{s}^{-1}\right]$,

$\mathbf{T}$... measuring time $[\mathrm{s}]$.

During the decomposition of mixed vibration into the frequency spectrum, $\mathbf{v}_{\text {ef }}$ can be determined in the relationship

$$
v_{\text {ef }}=\sqrt{\sum_{i=1}^{n} v_{\text {oefi }}^{2} \quad\left[\mathrm{~mm} . \mathrm{s}^{-1}\right], \text { where }}
$$

$\mathbf{V}_{\text {oefi }}$ is the i- $^{\text {th }}$ effective vibration velocity amplitude of the $\mathrm{i}^{\text {th }}$ harmonic spectrum component.

The maximum value of $\mathbf{v}_{\mathbf{e f}}$, measured on the important points of the machine, indicates the vibration severity $U$ according to:

$$
U=\left(x_{e f}, v_{e f}, a_{e f}\right)_{\max }
$$

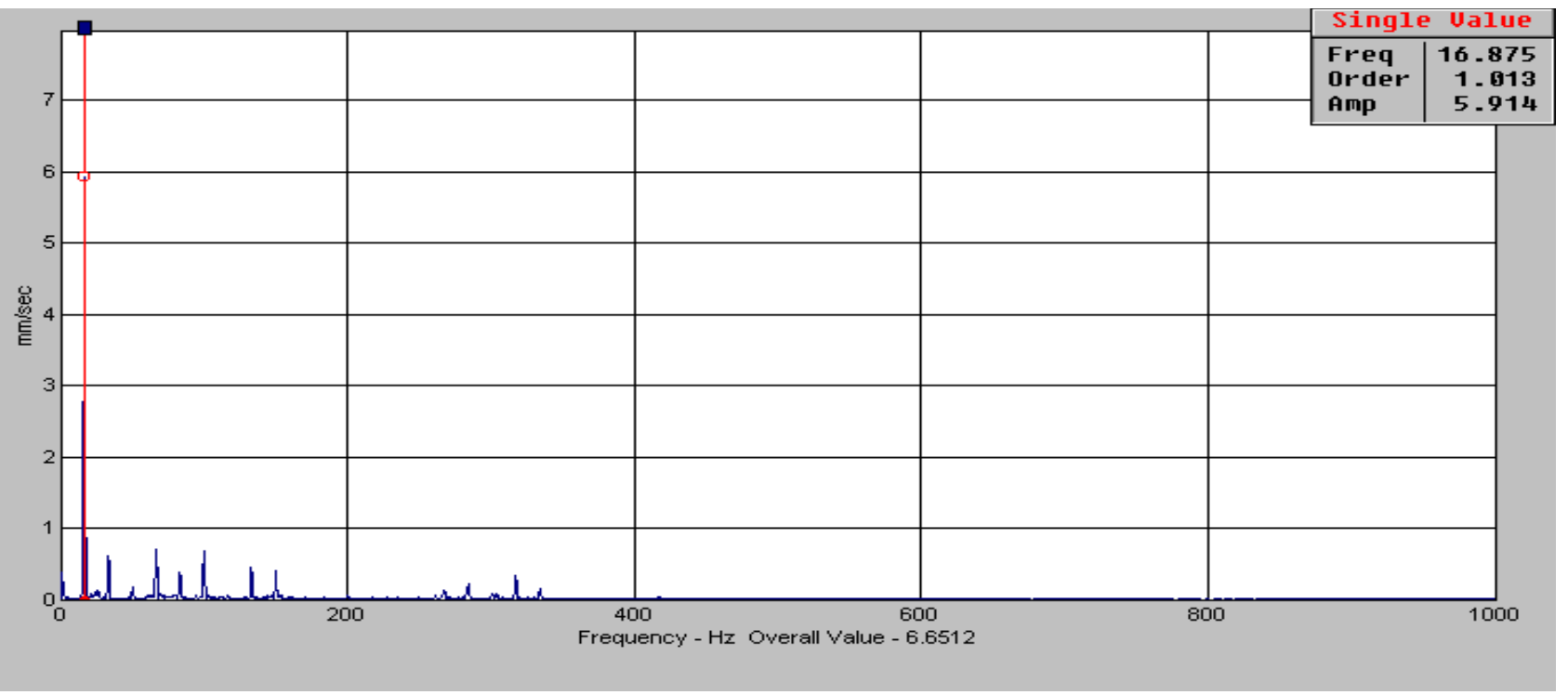

Figure 2. Vibration spectrum TG in $\mathbf{3 H}$ point before balancing and with load, RPM 1012, the amplitude of the rotor frequency $\mathrm{V}_{0}=5.91 \mathrm{~mm}, \mathrm{v}_{\mathrm{ef}}=6,65 \mathrm{~mm} \cdot \mathrm{s}^{-1}$.

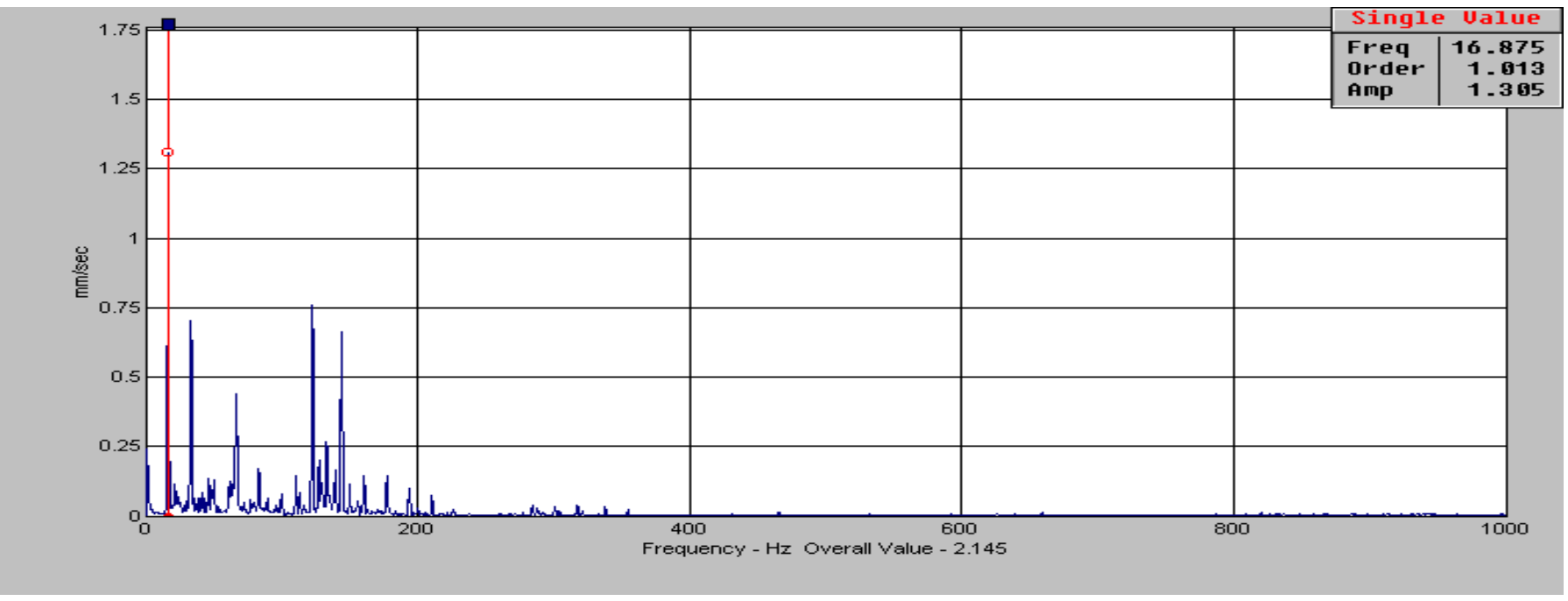

Figure 3. Vibration spectrum TG in $\mathbf{3 H}$ point after balancing and with load, RPM $=1012$, the amplitude of the rotor frequency $\mathrm{V}_{0}=1.38 \mathrm{~mm}, \mathrm{v}_{\mathrm{ef}}=2,14 \mathrm{~mm} \cdot \mathrm{s}^{-1}$. 


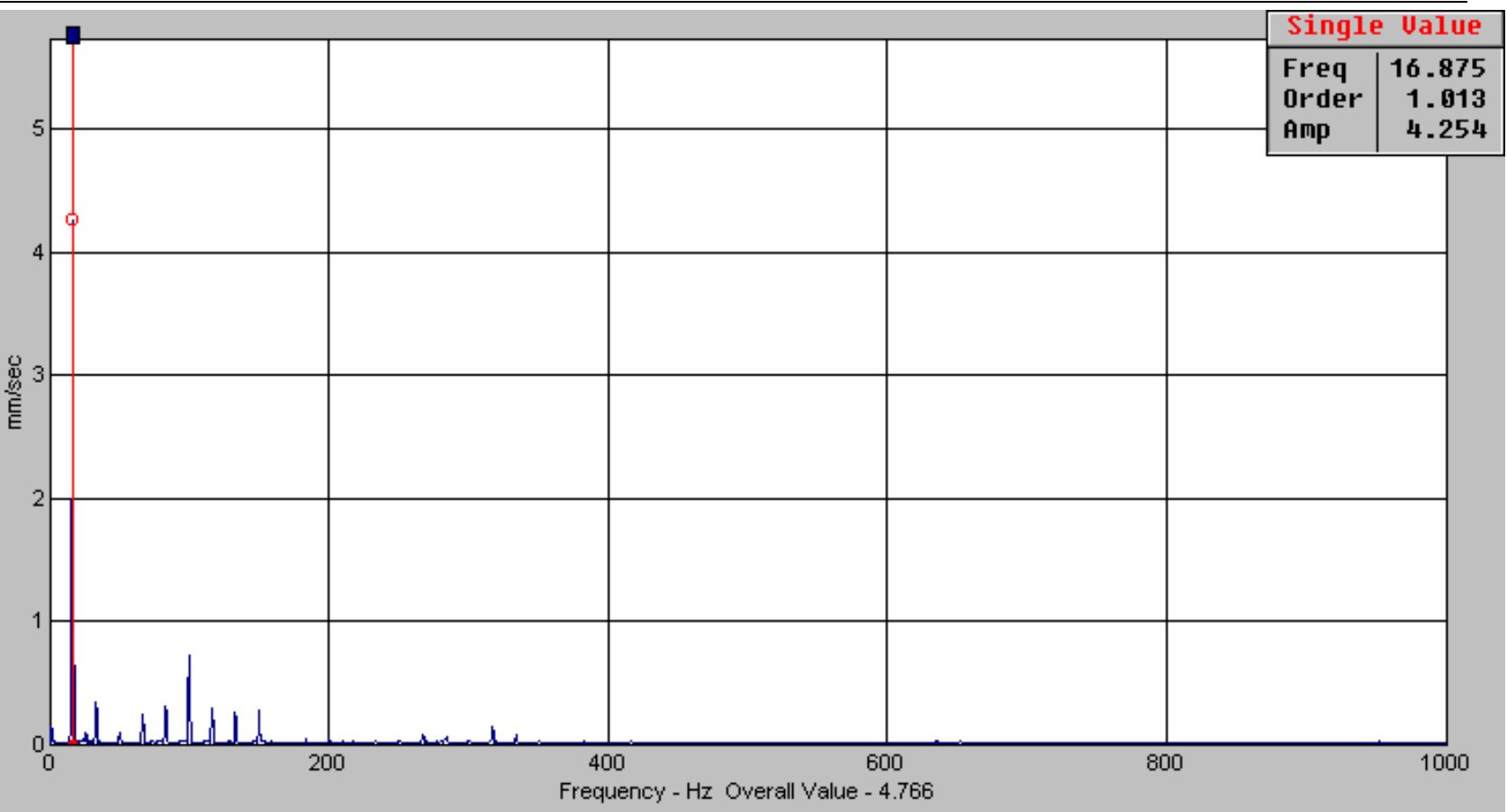

Figure 4. Vibration spectrum TG in $\mathbf{2 H}$ point before balancing and with load, RPM $=1008$, the amplitude of the rotor frequency $\mathrm{V}_{0}=4.25 \mathrm{~mm}, \mathrm{v}_{\mathrm{ef}}=4,766 \mathrm{~mm} \cdot \mathrm{s}^{-1}$.

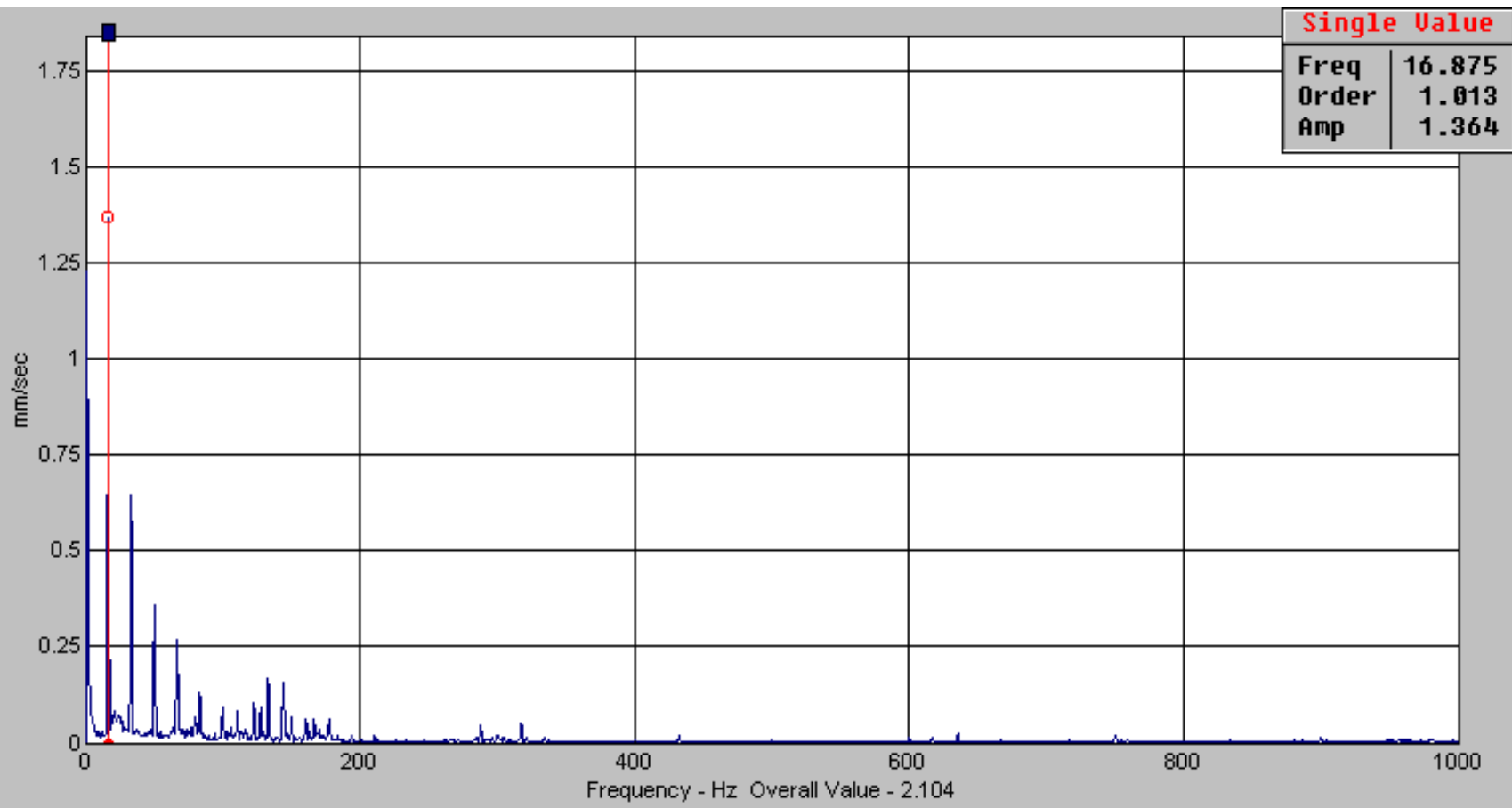

Figure 5. Vibration spectrum $T G$ in $\mathbf{2 H}$ point after balancing and with load, RPM $=1012$, the amplitude of the rotor frequency $\mathrm{V}_{0}=1.36 \mathrm{~mm}, \mathrm{v}_{\mathrm{ef}}=2,1 \mathrm{~mm} \cdot \mathrm{s}^{-1}$. 


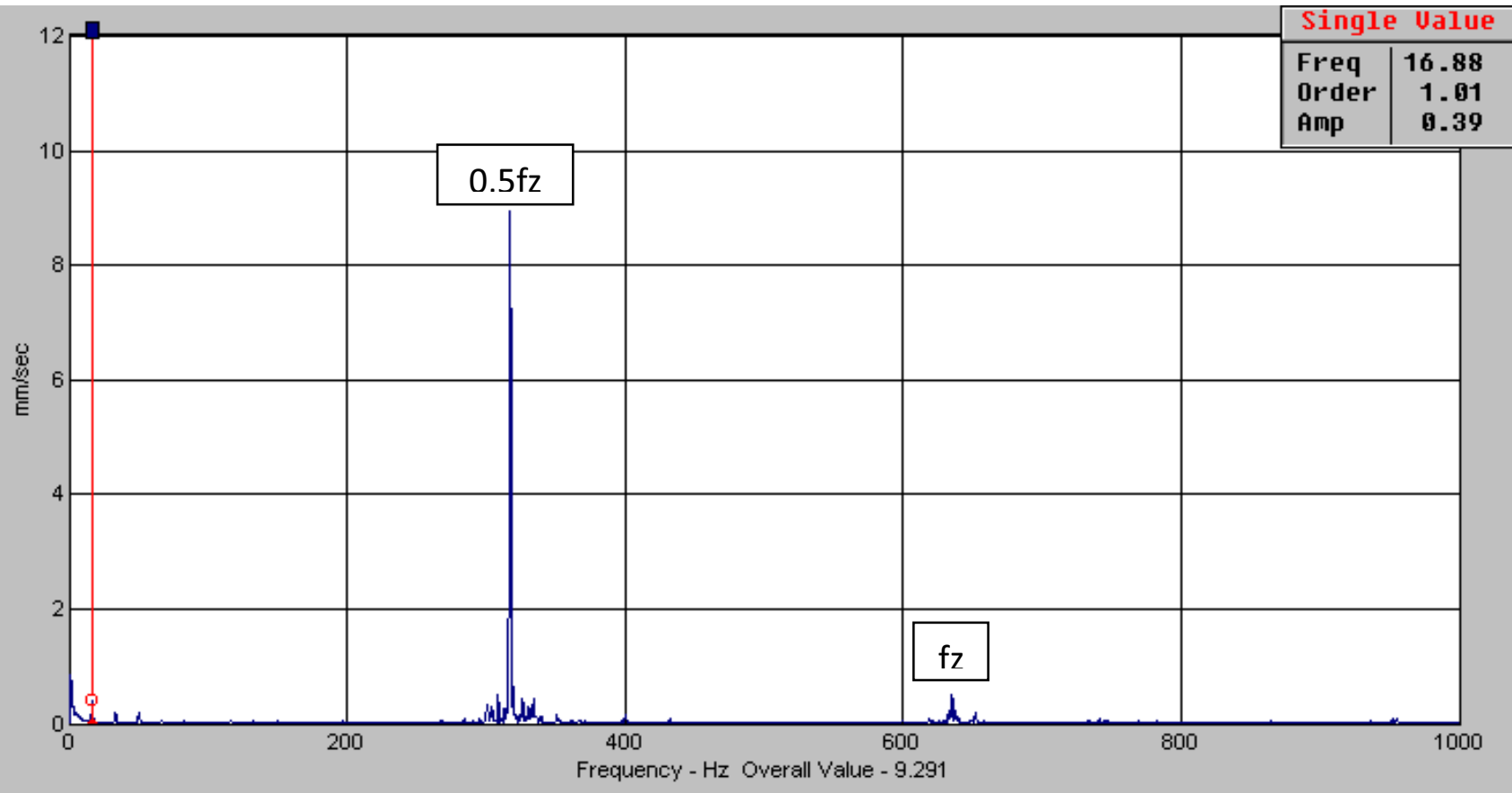

Figure 6. Vibration spectrum TG in $1 \mathbf{H}$ point before balancing and with load, RPM $=1008$, the amplitude of the rotor frequency

$\mathrm{V}_{0}=0.39 \mathrm{~mm}, \mathrm{v}_{\mathrm{ef}}=9,291 \mathrm{~mm} \cdot \mathrm{s}^{-1}$, the amplitude of gear frequency $0.51 \mathrm{~mm}$, the amplitude of gear frequency interharmonic component $0.5 \mathrm{f}_{\mathrm{z}}=8.93 \mathrm{~mm}$.

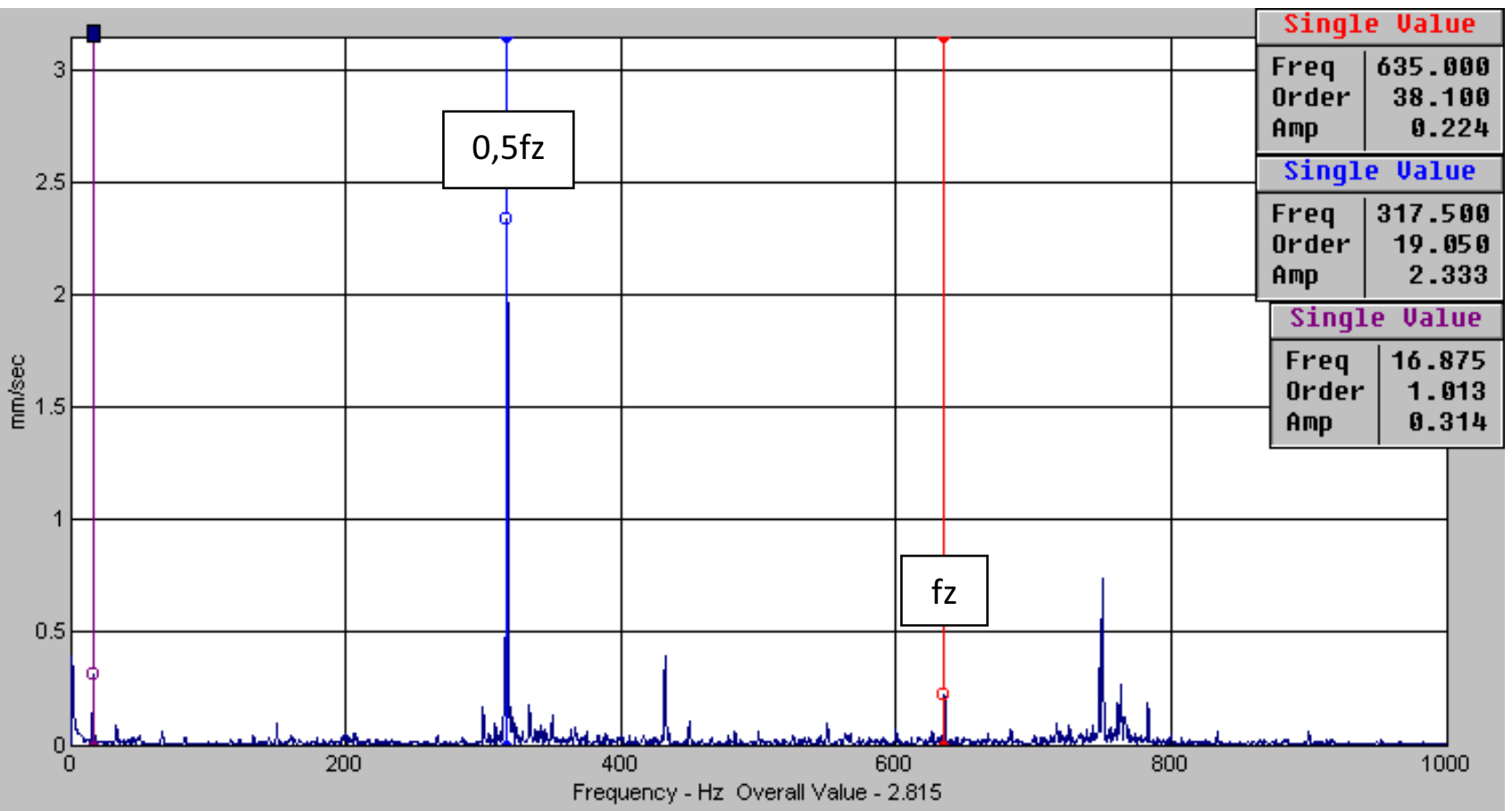

Figure 7. Vibration spectrum TG in $\mathbf{1 H}$ point after balancing and with load, RPM $=1012$, the amplitude of the rotor frequency $\mathrm{V}_{0}=0.3 \mathrm{~mm}, \mathrm{v}_{\mathrm{ef}}=2,815 \mathrm{~mm} \cdot \mathrm{s}^{-1}$, the amplitude of gear frequency $0.22 \mathrm{~mm}$, the amplitude of gear frequency interharmonic component $0.5 \mathrm{f}_{\mathrm{z}}=2.3 \mathrm{~mm}$. 


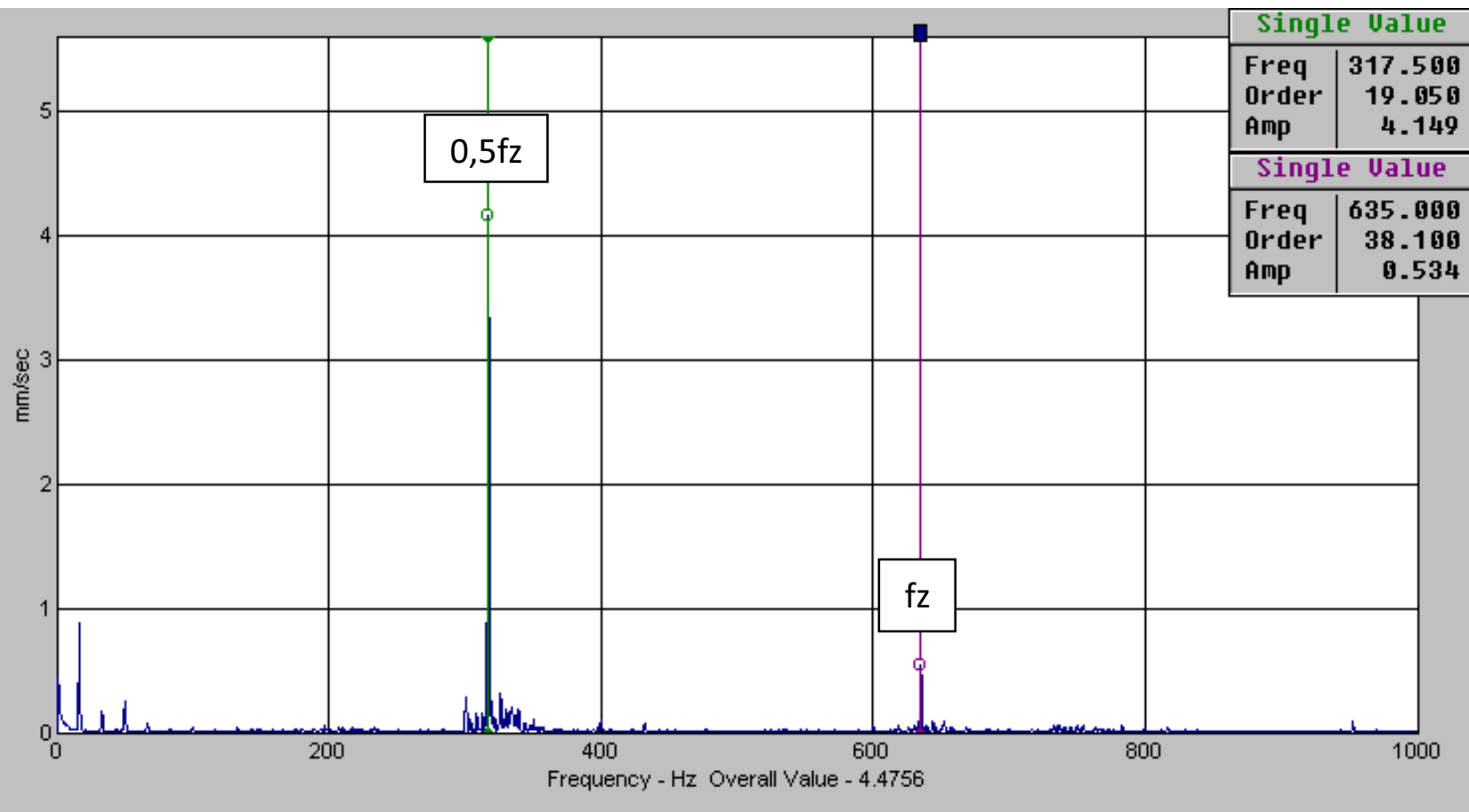

Figure 8. Vibration spectrum TG in $\mathbf{4 H}$ point before balancing and with load, RPM $=1012$, the amplitude of the rotor frequency $\mathrm{V}_{0}=0.87 \mathrm{~mm}, \mathrm{v}_{\mathrm{ef}}=4.47 \mathrm{~mm} \cdot \mathrm{s}^{-1}$, the amplitude of gear frequency $0.53 \mathrm{~mm}$, the amplitude of gear frequency interharmonic component $0.5 \mathrm{f}_{\mathrm{z}}=4.14 \mathrm{~mm}$.

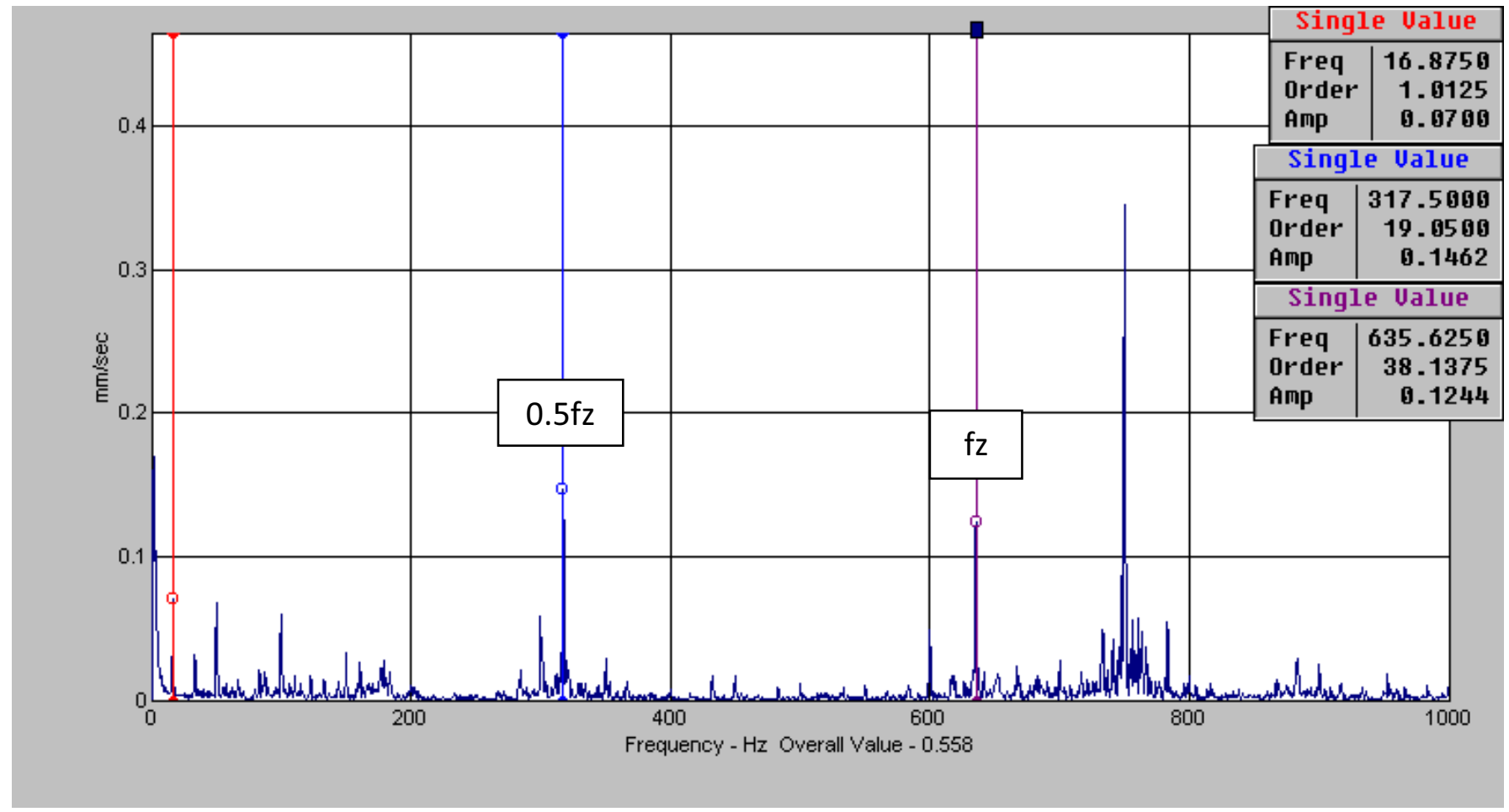

Figure 9. Vibration spectrum TG in $4 \mathbf{H}$ point after balancing and with load, RPM $=1012$, the amplitude of the rotor frequency $\mathrm{V}_{0}=0.07 \mathrm{~mm}, \mathrm{v}_{\mathrm{ef}}=0,55 \mathrm{~mm} . \mathrm{s}^{-1}$, the amplitude of gear frequency $0.12 \mathrm{~mm}$, the amplitude of gear frequency interharmonic component $0.5 \mathrm{f}_{\mathrm{z}}=0.14 \mathrm{~mm}$. 
For TG machine, the greatest level of vibration was measured at the turbine in the horizontal direction $1 \mathrm{H}$. The component of the frequency fz (gear frequency) and the component of the frequency fR (rotor frequency) determine the overall level of vibration. Because the amplitude V0 of the rotor frequency fR increases with the size of power and current, it can be said that the vibration excitation is directly related to the mechanical unbalance of the generator rotor flywheel.

The measurement demonstrated that the turbogenerator TG has at full power a quite high vibration level $\mathrm{U}=9.29 \mathrm{~mm} \cdot \mathrm{s}^{-1}$.

The analysis of the vibration measurements of the small hydroelectric power plant TG (Fig. 2, 4, 6 and 8) showed that the main cause of the excessive levels of vibration of flywheels and high noise pollution of gears is the unbalance of rotor turbine with the flywheel.

Standard ČSN ISO 10816 Vibration - is the basic document establishing general guidelines for the machines vibration measurement and evaluation. Criteria for evaluation of vibration were set especially with regard to ensuring a safe and long-term operation of machines. From the measured vibration severity, the small hydroelectric power generator TG, according to [1] can be allocated to Class II. According to article 5.3.1 of this norm, the TG machine can be classified in range $\mathrm{C}$ : $\mathrm{U}=$ 2.8 to $7.1 \mathrm{~mm} \cdot \mathrm{s}^{-1}$. Machines, whose vibration is in the $\mathrm{C}$ range, are normally considered as unsatisfactory for longterm continuous operation. Generally, the machines can operate under such conditions until we find the possibility of correction. It has been suggested to carry out an operational dynamic balancing of the machine flywheel by adding the correction weight in balancing plan 1 (131.7 g, phase angle $122^{\circ}$ ) and in balancing plan 2 (64.2 $\mathrm{g}$, phase angle 87.5). The TG results after balancing the machine flywheel rotor are listed in Tab. 1. and illustrated in Figure 5. and Figure 7.
The overall machine condition can be according to [1] and the measured overall vibration level evaluated as acceptable level of vibration. In case of continuous longterm operation of this generator, the life expectancy of the machine components will probably be lower.

For comparison the measured vibration severity is included:

- U = 2.7 [mm.s-1], a large turbine AESCH Switzerland

- U = 3.7 [mm.s-1], MVE Ervěnická corridor, sets 1

- U = 3.2 [mm.s-1], MVE Ervěnická corridor, sets 2

- U = 4.2 [mm.s-1], MVE MVE Orion Liberec

- U = 9.29 [mm.s-1], MVE Josefův Důl

The numerical values of vibration severity for the purpose of acceptance should be the subject of agreement between the machine manufacturer and the customer. The purchase agreement has to include:

- Machine inspection also on the basis of vibration and noise measurement,

- Cover of costs for the measurement and elimination of possible faults (tuning) reduction of the contract price of the machine.

EU directive for engineering requires that the measured vibration severity and the equivalent noise level be included in the documentation that accompanies the product.

Measurement and analysis of vibration (noise) are also useful in other areas of practice:

- Development of new machines - The measurement effectuated on manufactured machines provides an objective basis for the tuning and adjustment of machines - long life, high reliability and safety.

- Machine vendor selection - The name of the manufacturer, the price, service conditions and promotional data may not be decisive.

Table 1. Measured value of the total vibration level $\left[\mathrm{mm}_{\mathrm{s}} \mathrm{s}^{-1}\right]$ and significant components of the spectrum V0 with load $\mathrm{Pg}=100 \mathrm{~kW}$

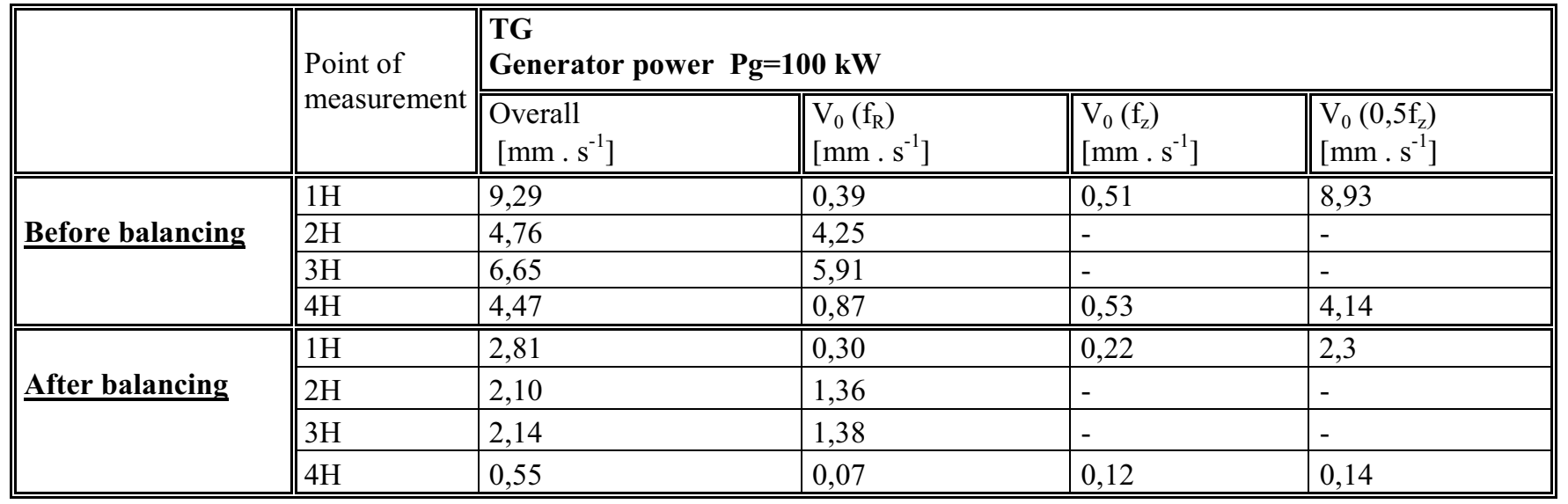




\section{Acquired knowledge}

The dynamic tuning of TG flywheel resulted in a significant decrease in the machine vibration and a significant reduction of gears noise.

Due to the elimination of flywheel unbalance in points $1 \mathrm{H}, 2 \mathrm{H}, 3 \mathrm{H}$ and $4 \mathrm{H}$, the overall level of vibration of the TG turbine decreased as well as the vibration frequencies amplitude corresponding to the rotor unbalance. At the same time, the amplitude of gear frequency and the amplitude of the interharmonic component frequencies ( 0.5 gear frequency) decreased. This interharmonic frequency of gears clearly shows the load on the pinion gear of the turbine wheel, due to flywheel unbalance. See Table 2 and graphs.

In this state the machine $\mathrm{TG}$ achieves long lifetime in continuous operation.

Table 2. The decrease in the size of the individual vibration components after balancing the TG flywheel

\begin{tabular}{|c|c|c|c|c|}
\hline \multicolumn{5}{|c|}{ The decrease in size of the individual vibration } \\
components $[\%]$
\end{tabular}

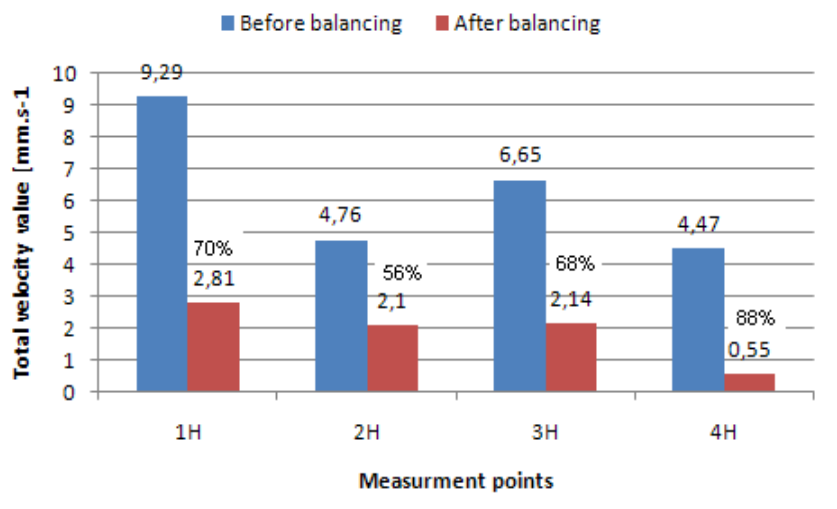

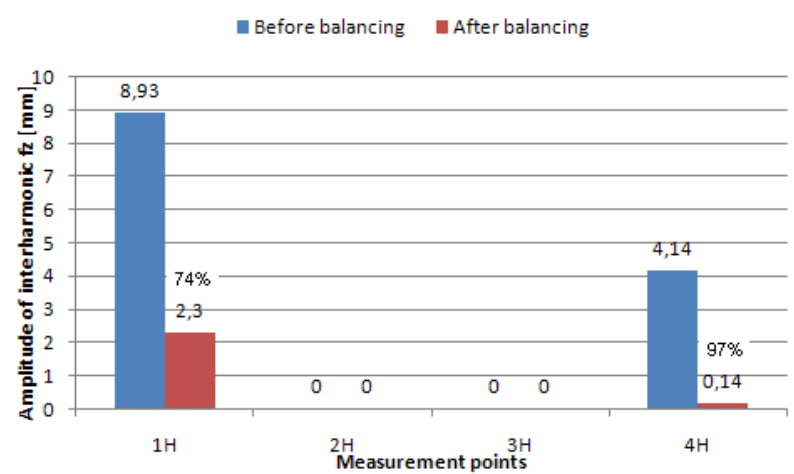

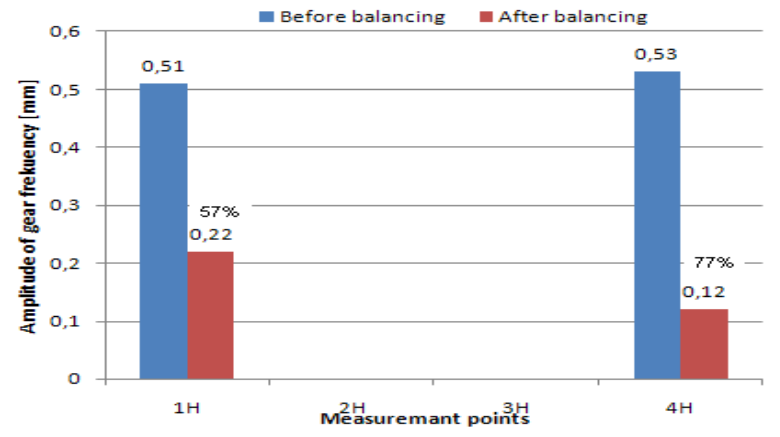

\section{References}

1. ČSN ISO 10 816-1 Vibrace - Hodnocení vibrací strojů na základě měření na nerotujících částech. Č́st 1: Všeobecné směrnice.

2. Beneš, $\breve{S}$. - Tomeh, E.: Posouzení vibrací malé vodní elektrárny Kolora Přepeře. TU Liberec 1995.

3. Angelo, M.: Monitorování mechanického chvění strojních zařízení. Brüel \& Kjaer 1987.

4. Tomeh, E.: Diagnostic Methodology of Rolling Element and Journal Bearings. /Skripta TU V Liberci/, TUL Liberec, 2007.

5. Tomeh, E.: Technická diagnostika - Vibrační diagnostika strojů a zařízení. /Skripta TU v Liberci/, TUL Liberec, 2015. 